\title{
The Influence of Organizational Communication Climate on Cisral Library Performance in Padjadjaran University
}

\author{
Rika Jufriazia Manita \\ rikajufriaziamanita@iainbatusangkar.ac.id \\ Institut Agama Islam Negeri Batusangkar \\ Benni Handayani \\ bennihandayani@comm.uir.ac.id \\ Universitas Islam Riau \\ Oktri Permata Lani \\ oktripermatalani@iainbatusangkar.ac.id \\ Institut Agama Islam Negeri Batusangkar
}

\begin{abstract}
This research raised about the effect Organizational Communication Climatic of CISRAL's Library Performance at the University of Padjadjaran, and also tells about every point of the indicator: trust, participatory decision making, openness in communication, listening in communication up to and think about the goals of high-performance. This research use survey descriptive and quantitative survey explanatory with path analysis which is used to determine the influence of the independent variable of organizational communication climate dimensions $(\mathrm{X})$ with the confidence indicator, participatory decision making, openness in communication, listening in communication up to and think about goals high performance to the performance of the library (Y). Based on the results of this study can be concluded the discussion of organizational communication climate influence directly and indirectly to the performance of the library at the University of Padjadjaran CISRAL.
\end{abstract}

Keywords: Climate Communication; Organizational Communication; Organizational Climate; Organizational Performance; Libraries Performance.

\section{INTRODUCTION}

The communication climate includes perceptions and events related to the messages that occurs within the organization, such as the way of employees to communicate with superiors or vice versa (Pace \& Faules 2006). The communication climate is related to the organization in the context of the concepts, feelings, and expectations of members, to explain the behavior of organizational members (Poole, 1985). Meanwhile, Climate itself is not the nature of an individual, but the nature that is formed, shared and maintained by members of the organization (Desrianita, 2018).

Then, Davis \& John (1995) stated that a more concentrated climate in humans results in higher levels of achievement and greater job satisfaction. Humane climate, which is full of support, cooperation, appreciation, and recognition, will further increase job satisfaction so that it will motivate subordinates to work more effectively. The treatment given to each 
organizational actor will be felt differently by each individual. In this case, the leader of an organization must be able to maintain and control emotions in giving statements and relationships with all employees, this equation is applied in order to create equality and recognition obtained by employees from their superiors in order to carry out agreed on work activities (Baihaqi, \& Suharnomo, 2010).

Still dealing with this case, if the relationship between superiors and subordinates or fellow subordinates is good, it will be able to provide a comfortable working atmosphere for librarians and education staff. Bosses are very instrumental in the progress of the library. It is the superiors who must encourage and encourage the subordinates to actualize themselves or fulfill needs such as the need for achievement. According to Gibson, Ivancevich and Donnelly (1994) good communication in the library can provide encouragement and good morale for individuals in the library. For example, Communication between superiors and subordinates or between fellow subordinates will be able to influence performance in the library.

A library is a room, part of a building, or the building itself that is used to store books and other publications that are usually stored according to a specific arrangement for readers to use, not for sale (Sulistyo, 1991). Moreover, the library actually consists of various types, depending on where the library is located and what functions were carried out by the library. For example in this case the college library, the task and function of the university library is to be a source of learning and teaching as part of the practice of achieving the three tridharma of the education, research and community service. Then the library was formed always to be a media that is able to provide services in this case information services both in print and digital form. Thus, the library must be prepared with a system that is committed and can be maintained in the long run, especially those related to library information retrieval guidelines.

Activities undertaken in achieving library work targets are based on four main elements namely procurement of collections, processing, service, and maintenance of library materials (Damayanty, 2012). Librarians and education staff work together to carry out these four important elements so that in the process of services provided to users can be maintained for a long time and the most important is the librarians and education staff can show their performance in front of users by providing services that lead to user satisfaction. The definition of performance is the work of quality and quantity achieved by an employee in carrying out their duties in accordance with the responsibilities given to him (Anwar, 2008).Thus, the intended performance is something that is obtained by someone (librarian and education staff) which is demonstrated by the quality of work and is maintained in a quantity manner in the presence of leaders, competitors and library users.

Besides that, all library employees in the library organizational structure must be invited to communicate and consult on all issues in the library policy area, which are relevant to their position. Library staff at all levels must be given the opportunity to communicate and consult thus they are expected to be able to participate in the decision making process and determining the library's objectives so that in this way each library employee will feel a deep responsibility when carrying out any given task so that the communication climate the good will be created in the library environment.

In the organization of employee performance varies depending on the type of work, whether the work in accordance with the expertise possessed. If the employee is placed in his area of expertise, the employee will have a high morale, automatically the performance of the employee will improve, and vice versa which will result in performance in the organization that is difficult to achieve. The performance of employees in the organization cannot be achieved optimally due to climate communication factors that exist within the organization is not good with the fundamental problem in the organization is located in its internal 
environment. Causing communication between employees has not gone well, as a result in carrying out the task is still not optimal. The initial step that needs to be taken in overcoming the problem is to improve the existing communication within the organization so that the communication climate runs as expected and employee performance will automatically improve.

\section{METHOD}

The research method used in this study is a descriptive survey and survey-explanatory approach. The descriptive approach is used to obtain facts, look for factual information, and try to describe the symptoms of ongoing practice (Nazir, 1985) while the explanatory approach is used to explain causal relationships through testing hypotheses between variables being studied.

By using the survey-explanatory approach method it is hoped that the results of this study can reveal how much the organizational communication climate $(\mathrm{X})$ influences the performance of the CISRAL Library at Padjadjaran University (Y). Further from the description of these variables, described as follows:

\section{Trust}

\section{Variable (X) Climate Communication Organizations include}

- Statement

- action

2. Participation in making decisions

- opinion

- Efforts to advance the unit

3. Openness in communication

- Receiving assignments

- honesty

4. Listen in communication to the top

- Openness among employees

- The openness of subordinates to employees

- Ease in conveying what is in the mind

5. Thinking about high-performance goals

- Discipline

- Member productivity.

- User Satisfaction

- Library visits per capita

- Availability of library material titles

- The level of use of library materials

Measurement of each variable in this study was carried out by giving respondents a series of stimuli in the form of variables, meaning using a questionnaire that can be seen in the appendix to this study. While the hypothesis test that will be used in this study is the Path Analysis model.

Path analysis techniques require the requirement that the data have a measurement level of at least intervals. Therefore, data that has ordinal measurement levels must be transformed 
into intervals. To change the measurement level from ordinal to the interval, it is carried out through the Successive Interval Method (MSI) with the following steps:

1. Based on the respondent's answer, for each statement, calculate the frequency of each answer.

2. Based on the frequency obtained for each statement, calculate the proportion of each answer.

3. Based on these proportions, for each statement, calculate the cumulative proportion for each answer choice.

4. For each statement, specify the boundary value for $\mathrm{Z}$ for each answer choice.

5. Calculate the scaling numeric value for each answer choice using the following formula:

$$
\text { ScalaValue }=\frac{(\text { DensityatLowerLimit-DensityatUpperLimit })}{(\text { AreaatBelowUpperLimit-AreaatBelowLowerLimit })}
$$

6. Calculate the score (the value of the transformation) for each answer choice with the following equation:

$$
\text { Score }=\text { ScaleValue }+ \text { ScaleValueMinimum }+1
$$

7. Path analysis is used to show the relationship that shows how much influence a particular variable has either directly or indirectly on several other variables. So in this case the problem is cause and effect. The term that will be used in this path analysis is the exogenous variable which is the causative variable (X). endogenous variables are due variables $(\mathrm{Y})$ which are other factors of exogenous variables.

The purpose of path analysis is to explain the direct and indirect effects of some variables as causal variables, on several other variables as outcome variables. There are two relationships between variables in the path analysis, namely:

1. Direct Influence. Changing direction in one direction from one variable to another.

2. Indirect Effects with the One-Way Arrow on one variable on another variable, then from another variable One-Way Arrow to the next variable.

\section{RESULT AND DISCUSSION}

\section{INFLUENCE OF TRUST ON LIBRARY PERFORMANCE IN 'CISRAL' LIBRARY}

Trust between employees in an organization will bring goodness. Especially if followed by a work-culture, it will bring good luck to the parties that trust each other. When mutual trust increases, communication within the organization will also increase. Mutual trust between employees in an organizational environment, sharing, interacting, and exchanging ideas will also increase work productivity within the organization and will show changes in the organization. According to Muhammad (2002: 19), communication involves a complex variation of interconnectedness that has never been duplicated in exactly the same way, namely: mutual relations between people, the environment, skills, attitudes, status, experience, and feelings, all of which determine communication which occurs at a certain time.

Based on statistical test results with a confidence level of $95 \%$ and a mistake of $5 \%$, it is known that Trust (X1) has a significant influence on Library Performance (Y). And the magnitude of the influence of Trust on Library Performance is $-41.42 \%$ of the total effect as a 
whole which is $94.9 \%$. Leaders should act fairly and care about the interests of employees, if that has been done well, then employee confidence in the leadership will grow. Leaders need subordinates, the leadership's work will not go well if there is no interference from subordinates.

Trust is the most valuable in human relationships. Lack of mutual trust within the organization will result in a decline in employee performance. Mutual trust in the CISRAL library environment will assist employees in carrying out their tasks so that they can improve the services provided to users. Open communication, exchanging important information, and involving employees in decision making are the ways leaders in the organization do so that no work is felt to be heavy. Nyhan (2000) says that to get the trust of his subordinates, a superior must be competent in his work, can be relied on by his subordinates, be open, and care for his subordinates.

\section{THE EFFECT OF PARTICIPATORY DECISION MAKING ON THE PERFORMANCE OF THE CISRAL LIBRARY}

Participatory decision-making indicators are opinions and efforts to advance the unit. Organizations in carrying out each activity will be more successful if the organization is able to increase the participation of its employees, especially in improving decision making. With the involvement of employees in the organization, employees will take responsibility for the organization. Participation is the key to solve problems faced by the organization. Participation in decision making can be done by various parties in the organization. With the participation, input, and information from employees can be used for the benefit of the organization, and also the relationships between employees with one another will be established. Based on statistical test results with a confidence level of $95 \%$ and a mistake of $5 \%$, it is known that Participatory decision making (X2) has a significant influence on Library Performance (Y). And the magnitude of the effect of participatory decision making on Library Performance is $44.92 \%$ of the total effect which is $94.9 \%$.

In increasing participation, sensitivity is needed for the organization and must have a sense of belonging to the organization, because employees play a direct role in making decisions and solving problems so as to increase job satisfaction. Ideally, all employees in the organization should provide ideas and opinions in decision making in the organization so that there will be no displeasure among employees. In addition, participation in decision making must be carried out honestly and democratically because decisions will affect the decisionmaker and the party representing them. Decisions must take into account the knowledge and opinions of the parties taking part in it so that no one is disappointed and efforts to advance the unit can be achieved.

The leaders of Padjadjaran University's CISRAL library listened to their opinions and included their staff in decision making. Trust between employees will be created because employees participate in providing ideas, input for the progress of the units they handle in the library. The participation of employees will make communication in the library open, employees can tell each other about the problems they face. In addition, employees and leaders can be close and share. Katz and Kahn's Social System Theory (Pace and Faules 2006) says the whole social system is composed of humans. He is not perfect but the continuity of his human relations is so high but still effective. Relationships between people, not the people themselves, allows an organization to last far longer than biological people who need leadership in the organization. Devito (1997) also said that all members of an organization must make a decision. Communication is one important tool in achieving these results. 
CISRAL library employees see that leaders listen to input from employees can be noticed from the full participation of leaders in decision making and able to solve serious problems and even synergize into something that is very dynamic and harmonious. Leaders can also reduce emotions both emotions and the emotions of other employees so that makes employees become comfortable at work. Employees are also not afraid to give opinions because the leader takes the middle way in solving problems. However, not all employees are involved in solving problems that exist in the organization but adjusted for the level of the problem that occurred. Relationships between employees and superiors or fellow employees who are good and listen to each other and give each other opinions will make the organization stronger, the organization can last longer and certainly the organization's goals in an effort to advance the unit will be achieved.

\section{THE EFFECT OF OPENNESS IN COMMUNICATION ON THE PERFORMANCE OF THE CISRAL LIBRARY}

Pollution in indicators is accepting assignments and honesty. Humans cannot communicate with each other, always communicating well with others. Humans communicate to meet the needs of both material and non-material. Likewise, in the organization. Employees need communication to depend on each other. According to Pace and Faules (2006) Organizations determine something that really encapsulates people, relationships, and goals. In addition, communication is needed in the organization to facilitate the coordination of work.

Based on the results of the statistics with a confidence level of $95 \%$ and a mistake of $5 \%$ which is recognized as Openness in Making Decisions (X3) does not provide a real orientation towards Library Performance (Y). And from the results of the evaluation, Participation in Decision Making only has an effect of $13.32 \%$ of the total effect of $94.9 \%$.

Openness in conversation in the CISRAL library environment has little difference to the library, meaning that the effect is small in statistics that tend to have their own inventory. Lack of openness in the CISRAL library environment will have an impact on the division of tasks assigned to employees who do not match or not in accordance with their expertise. Leaders do not support employees enough to be ineffective.

Openness between employees in the CISRAL library environment is very necessary because employees will be satisfied with the work they do if there is openness in communication. As a result, will improve library performance because of exchanging information. Examples of openness in the CISRAL library environment at Padjadjaran University are discussing issues of planning, development, monitoring, and evaluation based on coordinated plans, and available resources. This must be fully informed to all employees so that they can be understood, and discussed. In addition, leaders can also understand the development of employees associated with employees who always share and support leaders.

\section{EFFECTS OF LISTENING IN UPWARD COMMUNICATION ON CISRAL LIBRARY PERFORMANCE}

Listening in communication above has indicators of openness among employees, the openness of subordinates to employees, and ease in conveying the message that is in the mind. Listening in upward communication means that information coming from employees (subordinates) is conveyed to superiors (leaders) or information is conveyed from a lower level to a higher level. Information from subordinates is very valuable for decision making in the organization. With the communication above, it is very helpful for employees in 
overcoming their work problems while at the same time being able to strengthen employee involvement in their assigned tasks in the organization.

Based on statistical test results with a confidence level of $95 \%$ and a mistake of $5 \%$, it is known that Listening in Communication and Upward (X4) does not have a significant effect on Library Performance (Y). And from the test results, it is known that listening in Communication only has an effect of $22.59 \%$ of the total effect as a whole which is $94.9 \%$. The point is that communication to the top does not have a significant effect on library performance when viewed from testing per variable but has an influence when viewed from climate of organizational communication (variable $\mathrm{X}$ ) or as a whole. Its small effect in statistics is ignored because statistics have their own conditions.

If listening in upward communication (the leader listens to information from subordinates) is not implemented properly in the CISRAL Library environment, there will be obstacles in communication that result in decreased employee performance. Employees will be closed in providing information to superiors because employees feel scared and convey the information. Employees will not be open and will not report problems encountered so that the leadership will not know the problems that occur. This will make employees become lazy in carrying out their duties.

According to Pace and Faules (2001), a boss in addition to giving work orders or tasks to his subordinates must be willing to listen to subordinates' ideas and complaints and offer solutions to solve problems related to work, to create a harmonious communication atmosphere and organizational communication processes become effective. Trough effective communication, subordinates will feel their performance is appreciated, both parties can feel satisfied and comfortable with information, media, and relationships within the organization.

\section{THE EFFECT OF THINKING ON HIGH-PERFORMANCE GOALS ON LIBRARY PERFORMANCE}

Thinking about high-performance goals the indicators are discipline and productivity of members. One way is to increase employee productivity by improving the work environment for better quality of work. The work environment consists of physical and non-physical work environments which have a major influence on the smooth operation of the organization so that it will affect the productivity of the organization in general Productivity not only includes products and services but also affects processes, the environment, and humans. Therefore, a library must provide a quality environment so that its employees are comfortable so that it will increase work productivity. Based on statistical test results with a confidence level of 95\% and a mistake of 5\%, it is known that High-Performance Goals (X5) have a significant effect on Library Performance (Y). The magnitude of the effect of the High-Performance Goals on Library Performance is $55.48 \%$ of the total effect which is $94.9 \%$.

Improving employee performance needs role of leader. Leaders in the CISRAL library environment always provide encouragement and motivation to employees, namely by providing direction to employees about the clarity of tasks and management of the work environment. Leaders always communicate and pay attention to employees, as a result, employee morally increases which can be seen from the work completed on time. Communication that exists between employees and leaders increases employee performance, discipline, and motivation in terms of completing work in accordance with the target.

In any system of size, Swanson \& Gradous (1986) and Pace \& Faules (2006) interpreted that every employee's work in the library environment is interconnected and requires mutual cooperation. Employee cooperation created can improve employee performance because employees provide input to each other in completing work. If there is 
one employee who encounters difficulties then the other employee does not hesitate to offer help. Input from the leadership will also be a consideration for library staff in completing work. In accordance with the Social System Theory, Muhammad (2002) stated that the organization as a set of complex parts that are interconnected and integrated to adjust to the ever-changing environment in order to achieve its goals.

\section{INFLUENCE OF TRUST, PARTICIPATION, AND OPENNESS IN DECISION MAKING, LISTENING IN COMMUNICATION, AND HIGH-PERFORMANCE TOWARD LIBRARY PERFORMANCE}

The communication climate of an organization will affect the way of life of individuals in the organization such as: to whom to talk, who we like, how we feel, how we work, how we develop, what we want to achieve, and how we adapt with organization (Redding 1972). Pace \& Faules (2006) also said that "the climate communication of the organization is far more important than the skills or techniques of communication solely in creating an effective organization".

Based on statistical test results, it is known that overall Organizational Communication Climate variables consisting of Trust (X1), Participation in Making Decisions (X2), Openness in Making Decisions (X3), Listening in Communication (X4), and High-Performance Goals (X5) gives a real influence on Library Performance (Y). This can be seen from the F-Snodecor Test, which obtained the calculated $\mathrm{F}$ value $=93.073>\mathrm{F}$ table value $=2.60$ with, degrees $\mathrm{db} 1$ free $=5$, and $\mathrm{db} 2=31-5-1=25$. The magnitude of the effect of all independent variables on the dependent variable is $94.9 \%$. While the influence of other variables not included in the model is $5.1 \%$.

- Trust (X1) gives a significant effect on Library Performance (Y) with the approval of the $\mathrm{t}$ value $=-2.312>\mathrm{t}$ table $=-2.06$.

- Participation in making decisions (X2) gives a significant influence on Library Performance $(\mathrm{Y})$ by providing $\mathrm{t}$ arithmetic $=2.847>\mathrm{t}$ table $=2.06$.

- Openness in making decisions (X3) gives a significant influence on Library Performance $(\mathrm{Y})$ by providing $\mathrm{t}$ arithmetic $=1.030>\mathrm{t}$ table $=2.06$.

- Listening in communication (X4) gives a significant change to the Library Performance $(\mathrm{Y})$ by giving a value of $\mathrm{t}$ arithmetic $=1.639>\mathrm{t}$ table $=2.06$.

- High-Performance Objectives (X5) has a significant influence on Library Performance $(\mathrm{Y})$ by providing $\mathrm{t}$ arithmetic $=4.900>\mathrm{t}$ table $=2.06$.

Employees at all levels must increase the potential that exists in him because humans have their respective advantages. With these advantages, the employee must try his best to carry out the main tasks and give responsibilities to the organization. This must be applied by employees in order to provide good service to the community.

The CISRAL Library has guidelines and rules for improving the performance of its employees. All of this is stated in the CISRAL Strategic Plan, but the CISRAL Strategic Plan cannot be used as a guarantee in improving employee performance because not all employees apply it. Therefore, there must be awareness from employees in the CISRAL library to improve their performance. Self-motivation will improve performance in carrying out tasks and responsibilities. Excellent service can be applied to the community, especially visitors to the CISRAL library. CISRAL library staff must also know the purpose of CISRAL. Employees and leaders must be careful in seeing the problems that exist in the CISRAL environment, what is needed by the organization, and must be able to find solutions in overcoming problems that occur. 
Leaders are expected to listen to employee complaints about problems faced in their fields. Leaders must pay attention and encourage employees and provide opportunities for active employees and participate in providing input and decisions for the advancement of the CISRAL library.

A positive communication climate will provide an opportunity for employees to carry out their tasks creatively and provide innovative ideas and have a good influence in encouraging employees to exert all thoughts in carrying out work for the advancement of the CISRAL library. Mutual respect and respect for decisions and implement, utilize the information that can develop the CISRAL library. In accordance with Scot 1961's system theory (Pace and Faules 2006: 63) states that "the only meaningful way to study organizations is as a system. He argued that the important parts of the organization as a system are the individuals and personalities of everyone in the organization: formal structures, informal patterns of interaction, status patterns and roles that give rise to expectations and the physical environment of work.

A positive communication climate will provide an opportunity for employees to carry out their tasks creatively and provide innovative ideas and have a good influence in encouraging employees to exert all thoughts in carrying out work for the advancement of the CISRAL library. Mutual respect for decisions and implementation, utilizing information can develop the CISRAL library. In accordance with the 1961 Scot system theory Pace \& Faules (2006) states that "the only meaningful way to study organizations is as a system. He argues that the important parts of the organization as a system are the individuals and personalities of everyone in the organization: formal structures, informal patterns of interaction, status patterns and roles that give rise to expectations and the physical environment of work.

\section{CONCLUSION}

1. The influence of trust on the performance of the CISRAL library at UNPAD partially had a negative effect (when trust decreased, employee performance increased) but not significantly. This means that trust actually has an influence on the performance of the CISRAL library, but the effect is very small in that there is a negative influence.

2. The effect of participation in making joint decisions on the performance of the CISRAL library in UNPAD is partially positive (when participation makes joint decisions increase employee performance also increases) and significant. This means that participation in joint decision-making has a large influence on the performance of the CISRAL library.

3. The effect of openness in communication on the performance of the CISRAL library in UNPAD partially had a positive effect (when openness in communication increased the library performance also increased) but not significantly. This means that openness in communication actually has an influence on the performance of the CISRAL library, but a small effect is that there is a positive influence.

4. The effect of listening in upward communication on the performance of the CISRAL library at UNPAD partially has a positive effect (when listening in upward communication increases then the performance also increases) but not significantly. This means that listening in upward communication actually has an influence on the performance of the CISRAL library, but the small effect is that there is a positive influence.

5. The effect of thinking about high-performance goals on the performance of the CISRAL library at UNPAD is partially positive influence (when thinking about high-performance goals increases then library performance also increases) and significant (the effect is very 
clear and large). This means thinking about high-performance goals has a very big influence on the performance of the CISRAL library.

\section{ACKNOWLEDGEMENT}

We would like to thank all reviewers of the International Journal of Media and Communication Research for their comments and suggestions regarding this paper

\section{REFERENCES}

Anwar, P.M. (2008). Manajemen Sumber Daya Manusia Perusahaan. Bandung: Remaja Rosda Karya.

Arifin, Y. (2010). Kinerja Pelayanan e-Government. Bandung: Unpad Press

Baihaqi, M. F., \& Suharnomo, S. (2010). Pengaruh Gaya Kepemimpinan Terhadap kepuasan Kerja dan Kinerja dengan Komitmen Organisasi sebagai Variabel Intervening (studi pada pt. yudhistira ghalia indonesia area yogyakarta). Doctoral dissertation, Universitas Diponegoro.

Brahmasari, I. A., \& Suprayetno, A. (2008). Pengaruh motivasi kerja, kepemimpinan dan budaya organisasi terhadap kepuasan kerja karyawan serta dampaknya pada kinerja perusahaan (Studi kasus pada PT. Pei Hai International Wiratama Indonesia). Jurnal Manajemen dan kewirausahaan, 10(2), 124-135.

Damayanty. (2012). Sistem Layanan Informasi di Perpustakaan pada Abad ke-21. EduLib,2(1), 75-115.

Davis, K dan John W. (1995). Perilaku dalam organisasi. Penerjemah: Agus Dharma. Jakarta: Erlangga.

Desrianita, D. (2018). Communication Climate on Palu Trashbag Communities. Social humanity, 2(1), 56-80.

Devito, J. A. (1997). Komunikasi antar manusia. Jakarta: Professional Books.

Muhammad, A. (2002). Komunikasi Organisasi. Jakarta: Bumi Aksara.

Nazir, M. (1985). Metode Penelitian. Jakarta: Ghalia Indonesia.

Nyhan, R.C. (2000). Changing the Paradigm Trust and Its Role in Public Sector Organizations, Journal of American Review of Public Administration, 3 (1).

Pace, R. W., Faules, D. F., \& Mulyana, D. (2006). Komunikasi organisasi: strategi meningkatkan kinerja perusahaan. PT Remaja Rosdakarya.

Poole, M. S. (1985). Communication and organizational climates: Review, critique, and a new perspective. Organizational communication: Traditional themes and new directions, 13, 79-108.

Sulistyo, B. (1991). Pengantar Ilmu Perpustakaan. Jakarta: Gramedia Pustaka Utama.

Yusup, P. M. (1995). Pedoman Praktis Mencari Informasi. Bandung: PT Remaja Rosdakarya.

Scott, W. G. (1961). Organization theory: an overview and an appraisal. Academy of Management Journal, 4(1), 7-26. 


\section{ABOUT THE AUTHORS}

Rika Jufriazia Manita is a lecturer in Communication Sciences Department, Institute Agama Islam Batusangkar, West Sumatera, Indonesia.

Benni Handayani is a lecturer in Communication Sciences Department, Faculty of Communication, Universitas Islam Riau, Pekanbaru Indonesia.

Oktri Permata Lani is a lecturer in Communication Sciences Department, Institute Agama Islam Batusangkar, West Sumatera, Indonesia. 